\title{
Crystal Structure of 2,4-Bis(4-chlorophenyl)-3-azabicyclo[3.3.1]nonan-9-one
}

\author{
S. Natarajan, ${ }^{* \dagger}$ K. Uthayasankari, $*$ J. Sakthikumaran, ${ }^{* *}$ V. ViJayakumar, ${ }^{* *}$ \\ C. Gangadurai, $* *$ and J. Suresh $* * *$ \\ *Department of Physics, Madurai Kamaraj University, Madurai 625 021, India \\ **Department of Chemistry, VIT University, Vellore - 632 014, India \\ ***Department of Physics, The Madura College, Madurai 625 011, India
}

\begin{abstract}
The crystal structure of the title compound, $\mathrm{C}_{20} \mathrm{H}_{19} \mathrm{NOCl}_{2}$, confirms that the bicyclic ring system adopts the chair-chair conformation. The phenyl rings are equatorially disposed with respect to the bicyclic ring. There is a slight deviation from the chair conformation in the case of the cyclohexane ring.
\end{abstract}

(Received February 15, 2008; Accepted May 12, 2008; Published on web July 1, 2008)

Azabicyclononane and their derivatives are studied intensively because of their pharmaceutical use and their application as an important structure in the field of molecular recognition. The 3azabicyclo[3.3.1]nonane skeletal system, which is easily constructed $^{1}$ via a double Mannich reaction, has been known for some time. The bicyclo[3.3.1]nonane carbon framework is frequently encountered in natural products, particularly in alkaloids and terpenoids, e.g. clovene,$^{2}$ upial, ${ }^{3}$ and trifarienols. ${ }^{4}$

Cyclohexnanone $(0.02 \mathrm{~mol})$, 4-chlorobenzaldehyde $(0.04$ $\mathrm{mol})$, dry ammonium acetate $(0.02 \mathrm{~mol})$ and ethanol $(10 \mathrm{~mL})$ were taken and heated until ammonium acetate dissolved. The mixture was allowed to stand until no more solid gets separated. When the turbidity appeared to be sufficient, ether was added to keep the mixture clear. The separated solid was filtered off and recrystallized from a chloroform-benzene mixture. The purity of the compound was checked by TLC, and the melting point was recorded. Yield: $25 \%$, M.P. $154^{\circ} \mathrm{C}$.

The crystal and experimental details are given in Table 1 . The structure was solved by direct methods and refined by fullmatrix least-squares procedures to a final reliability value of 0.0368. $\mathrm{H}$ atoms were placed at calculated positions and allowed to ride on their carrier atoms with $\mathrm{C}-\mathrm{H}=0.93-0.97 \AA$, $\mathrm{N}-\mathrm{H}=0.86 \AA$ and $U_{\text {iso }}=1.2 U_{\text {eq }}(\mathrm{C}, \mathrm{N})$ for the $\mathrm{CH}_{2}, \mathrm{CH}$ and $\mathrm{NH}$ groups. The atomic coordinates and temperature factors for the non-hydrogen atoms are presented in Table 2.

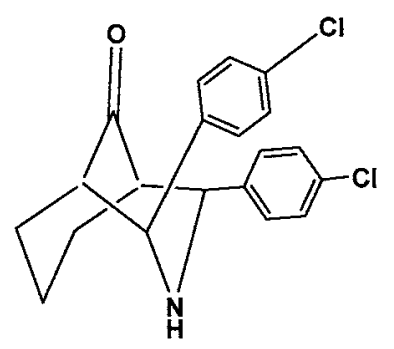

Fig. 1 Chemical diagram.

† To whom correspondence should be addressed.

E-mail: s_natarajan50@yahoo.com
Figurre 1 shows a chemical diagram and Fig. 2 a thermal ellipsoid plot of the complex. The bicyclic[3.3.1]nonane ring can exist in chair-chair, chair-boat and boat-boat conformations. Among these, the chair-chair conformation is the most favorable one. From the present study of the title compound, it is found that the bicyclic ring system adopts the chair-chair conformation, as in related structures previously studied. 5,6 In the cyclohexane ring of the compound, atoms $\mathrm{C} 11$ and $\mathrm{C} 13$ deviate from the $\mathrm{C} 10 / \mathrm{C} 12 / \mathrm{C} 14 / \mathrm{C} 15$ plane by -0.707 (3) and $0.556(3) \AA$, respectively, indicating a departure from the ideal chair conformation. These values are found to be

Table 1 Crystal and experimental data

\begin{tabular}{ll}
\hline Empirical formula & $\mathrm{C}_{20} \mathrm{H}_{19} \mathrm{NO} \mathrm{Cl}_{2}$ \\
Formula weight & 362.28 \\
Temperature & $293(2) \mathrm{K}$ \\
Wavelength & $0.71073 \AA$ \\
Crystal system, space group & Triclinic, $\mathrm{P} \overline{1}$ \\
Unit cell dimensions & $a=8.284(8) \AA$ \\
& $b=10.665(10) \AA$ \\
& $c=11.131(11) \AA$ \\
& $\alpha=72.94(17)^{\circ}$ \\
& $\beta=71.88(15)^{\circ}$ \\
& $\gamma=88.07(20)^{\circ}$ \\
Volume & $891.67(15) \AA^{3}$ \\
$Z$, Calculated density & $2,1.342 \mathrm{Mg} / \mathrm{m}^{3}$ \\
Absorption coefficient & $0.370 \mathrm{~mm}{ }^{-1}$ \\
$\theta_{\text {max }}$ & 25 \\
Reflections collected/unique & $3840 / 3127$ \\
Refinement method & Full-matrix least-squares on $F^{2}$ \\
Goodness-of-fit on $F^{2}$ & 1.029 \\
Final $R$ indices & $R 1=0.0368$, \\
{$[I>2 \theta(I)]$} & $w R 2=0.0964$ \\
$R$ indices (all data) & $R 1=0.0493$ \\
& $w R 2=0.1046$ \\
Largest diff. peak and hole & 0.549 and \\
& -0.524 e. $\AA^{-3}$ \\
Measurement & Enraf Nonius-CAD4 \\
Structure determination & SHELXS97 \\
Refinement & SHELXL97 \\
Structure drawing & ORTEP \\
&
\end{tabular}


Table 2 Fractional atomic coordinates $\left(\times 10^{4}\right)$ and equivalent isotropic displacement parameters $\left(\AA^{2} \times 10^{3}\right)$

\begin{tabular}{ccccc}
\hline Atom & $x$ & $y$ & $z$ & $U(\mathrm{eq})$ \\
\hline $\mathrm{C}(1)$ & $2961(3)$ & $1847(2)$ & $5598(2)$ & $44(1)$ \\
$\mathrm{C}(10)$ & $3706(3)$ & $1284(2)$ & $823(2)$ & $48(1)$ \\
$\mathrm{C}(11)$ & $3844(3)$ & $326(2)$ & $2079(2)$ & $53(1)$ \\
$\mathrm{C}(12)$ & $2699(3)$ & $634(2)$ & $3282(2)$ & $45(1)$ \\
$\mathrm{C}(13)$ & $545(3)$ & $1329(2)$ & $1984(2)$ & $56(1)$ \\
$\mathrm{C}(14)$ & $838(3)$ & $581(2)$ & $3291(2)$ & $52(1)$ \\
$\mathrm{C}(15)$ & $1898(3)$ & $1106(2)$ & $793(2)$ & $58(1)$ \\
$\mathrm{C}(16)$ & $3930(2)$ & $3707(2)$ & $-391(2)$ & $39(1)$ \\
$\mathrm{C}(17)$ & $4858(3)$ & $3699(2)$ & $-1670(2)$ & $47(1)$ \\
$\mathrm{C}(18)$ & $4559(3)$ & $4560(2)$ & $-2768(2)$ & $51(1)$ \\
$\mathrm{C}(19)$ & $3325(3)$ & $5450(2)$ & $-2587(2)$ & $48(1)$ \\
$\mathrm{C}(2)$ & $2065(3)$ & $2072(2)$ & $6781(2)$ & $47(1)$ \\
$\mathrm{C}(20)$ & $2403(3)$ & $5493(2)$ & $-1337(2)$ & $50(1)$ \\
$\mathrm{C}(21)$ & $2714(3)$ & $4616(2)$ & $-248(2)$ & $45(1)$ \\
$\mathrm{C}(3)$ & $661(3)$ & $2803(2)$ & $6833(2)$ & $44(1)$ \\
$\mathrm{C}(4)$ & $161(3)$ & $3327(2)$ & $5727(2)$ & $48(1)$ \\
$\mathrm{C}(5)$ & $1080(3)$ & $3100(2)$ & $4547(2)$ & $45(1)$ \\
$\mathrm{C}(6)$ & $2479(2)$ & $2348(2)$ & $4466(2)$ & $38(1)$ \\
$\mathrm{C}(7)$ & $3418(2)$ & $1983(2)$ & $3225(2)$ & $40(1)$ \\
$\mathrm{C}(9)$ & $4229(2)$ & $2686(2)$ & $784(2)$ & $41(1)$ \\
$\mathrm{Cl}(1)$ & $-517(1)$ & $3071(1)$ & $8327(1)$ & $70(1)$ \\
$\mathrm{Cl}(2)$ & $2916(1)$ & $6521(1)$ & $-3965(1)$ & $73(1)$ \\
$\mathrm{N}(1)$ & $3329(2)$ & $2974(2)$ & $2025(1)$ & $40(1)$ \\
$\mathrm{O}(1)$ & $4776(3)$ & $-571(2)$ & $2119(2)$ & $84(1)$ \\
\hline
\end{tabular}

$U$ eq $=(1 / 3) \sum_{\mathrm{i}} \sum_{\mathrm{j}} a_{\mathrm{i}} * a_{\mathrm{j}} *\left(\boldsymbol{a}_{\mathrm{i}} \cdot \boldsymbol{a}_{\mathrm{j}}\right)$

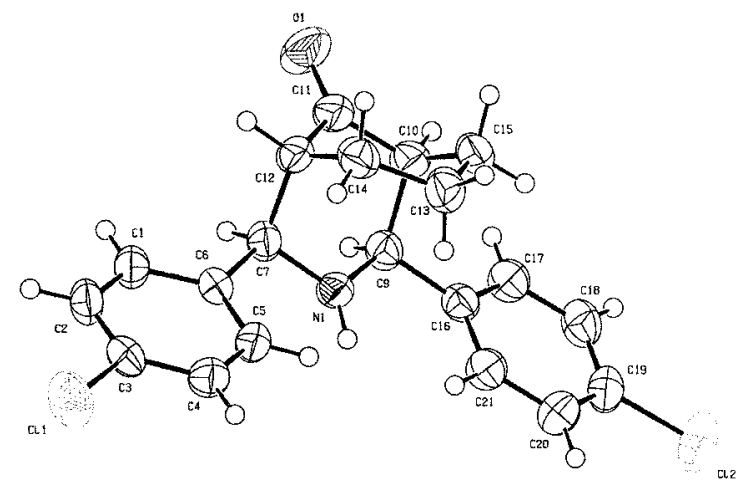

Fig. 2 ORTEP of the molecule at $50 \%$ probability.

$-0.732(2)$ and $0.540(3) \AA$ and 0.720 and $-0.537(4) \AA$ in the cyclohexanes of the related compounds.5,6 The piperidine ring has near ideal chair conformation. The planar phenyl rings are oriented at an angle of $16.8(1)^{\circ}$ to each other, and are equatorially disposed with respect to the piperidine ring, with the torsion angles being C11-C10-C9-C16 = -173.9(2) ${ }^{\circ}$ and

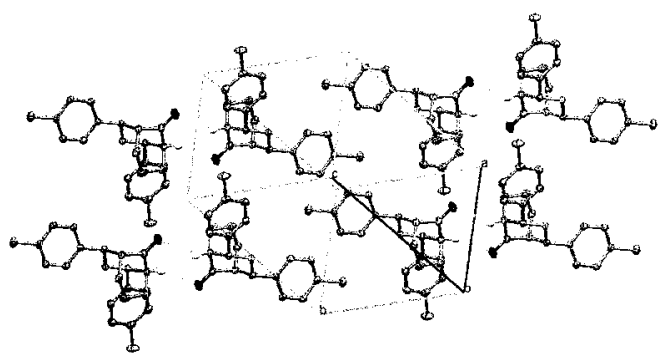

Fig. 3 Packing diagram showing the $R_{2}^{2}(8)$ motif.

Table 3 Hydrogen bonding geometry $\left(\AA,^{\circ}\right)$

\begin{tabular}{ccccc}
\hline $\mathrm{D}-\mathrm{H} \cdots \mathrm{A}$ & $\mathrm{d}(\mathrm{D}-\mathrm{H})$ & $\mathrm{d}(\mathrm{H} \cdots \mathrm{A})$ & $\mathrm{d}(\mathrm{D} \cdots \mathrm{A})$ & $\angle(\mathrm{DHA})$ \\
\hline $\mathrm{C}(10)-\mathrm{H}(10) \cdots \mathrm{O}(1)^{\mathrm{i}}$ & 0.98 & 2.53 & $3.423(2)$ & 152 \\
$\mathrm{C}(14)-\mathrm{H}(14 \mathrm{~A}) \cdots \mathrm{Cg}(1)^{\mathrm{ii}}$ & 0.97 & 2.72 & $3.662(2)$ & 163 \\
\hline
\end{tabular}

(i) $1-x,-y,-z$

(ii) $-x,-y, 1-z \mathrm{Cg}(1)$ is $\mathrm{C} 1-\mathrm{C} 6$ centroid

C11-C12-C7-C6 $=-174.2(2)^{\circ}$. The corresponding values in a related compound ${ }^{6}$ are $179.2(2)^{\circ}$ and $177.9(2)^{\circ}$. These differences in the values are possibly due to differences in the substituent atoms.

There is a $\mathrm{C}-\mathrm{H} \cdots \mathrm{O}$ hydrogen bond between the molecules related through a center of inversion, leading to the formation of centrosymmetric dimers generating a graph set motif, $R_{2}^{2}(8)$ (Table 3, Fig. 3). In addition, there is a $\mathrm{C}-\mathrm{H} \cdots \pi$ interaction (Table 3).

\section{Acknowledgements}

The authors thank the DST for the FIST support.

\section{References}

1. R. Jeyaraman and S. Avila, Chem. Rev., 1981, 81,149.

2. A. W. Lutz and E. B. Reid, J. Chem. Soc., 1954, 2265.

3. G. Scheuer and P. J. Mc Connell, J. Org. Chem., 1980, 45, 552.

4. Y. Asakawa in Progress in the Chemistry of Organic Natural Products, ed. G. W. Moore, R. E. Steglich, W. Tamm, Springer-Verlag, New York, 1995, 65, 208.

5. N. Sampath, S. M. Malathy Sony, M. N, Ponnuswamy, and M. Nethaji, Cryst. Res. Technol., 2004, 39, 821

6. L. Vijayalakshmi, V. Parthasarathi, M. Venkatraj, and R. Jeyaraman, Acta Cryst., 2000, C56, 1240. 